\title{
Militær ledelse: Kunst, håndværk eller videnskab?
}

\author{
Af Therese Heltberg og Kristian Broboek Madsen *)
}

\begin{abstract}
Resumé
Er militær ledelse en kunst? Et håndværk? Eller en videnskab? Med afsæt i en analyse af begrebet militær ledelse viser artiklen, hvordan arbejdet med metaforer har en helt central organisatorisk funktion og kan udgøre et væsentligt redskab til udvikling af organisationer og professioner. Artiklen præsenterer dels en teoretisk udfoldelse af og refleksion over, hvad vi kan få blik for, hvis vi betragter metaforer som et perspektiv. Dels undersøger artiklen konkret, hvordan tre forskellige metaforiske forståelser af militær ledelse - som henholdsvis en kunst, et håndværk eller en videnskab - har afgørende betydning for, hvordan den militære organisation vurderer og udvikler sine militære ledere.
\end{abstract}

Emneord: Militær ledelse, metaforer, professionsudvikling, ledelsesudvikling, kunst, håndværk, videnskab

*) Therese Heltberg er forsker ved Forsvarsakademiet, og Kristian Brobæk Madsen er udvikler ved Forsvarsakademiet. 


\section{A. Indledning}

\section{Artiklens formål}

Denne artikel udforsker, hvilken rolle metaforer kan spille i optegningen og organiseringen af officersprofessionen. Igennem denne udforskning ønsker vi samtidig at foreslå metaforarbejde som en måde, hvorpå professioner generelt kan arbejde med deres egen udvikling. Officersprofessionen rummer forskellige facetter, som beskrives nærmere senere i artiklen. Det primære fokus for vores analyse og refleksion er den del af officersprofessionen, der beskæftiger sig med militær ledelse. I artiklen søger vi at besvare spørgsmålet: Hvilken betydning kan de metaforer, vi anvender om begrebet militoer ledelse, have for vores måder at udvikle og vurdere militore ledere? Vi gennemfører denne undersøgelse ved at koble en ledelsesmodel fra Mintzberg $(2005,2009)$ med metaforteori og undersøger i forlængelse heraf, hvilke implikationer metaforerne kunst, håndværk og videnskab hver især kan have for militær ledelse. ${ }^{i}$ Vi illustrerer dette med konkrete eksempler fra Forsvaret.

Et centralt formål med artiklen er at vise, hvordan metaforiske forståelser af begreber rummer implicitte antagelser og mulige implikationer. Metaforer er dermed ikke neutrale, men bidrager til at forme og strukturere organisatoriske valg og konfigurationer, ofte uden at vi er opmærksomme på det. I relation til artiklens genstandsfelt søger vi ikke at definere, hvad militær ledelse er, eller hvordan det eksempelvis adskiller sig fra civil ledelse. I stedet undersøger vi forskellige måder at iagttage militær ledelse på for at se, hvilke betydninger disse forskellige iagttagelsespositioner får for praksis. Hermed er der tale om en andenordens-iagttagelse - det vil sige en iagttagelse af iagttagelsen - af egen praksis og egne antagelser. Artiklens udgangspunkt er, at begrebsliggørelsen af militær ledelse hele tiden pågår, og at brug af metaforer kontinuerligt bidrager til at forme mulighedsrummet for ledelse ved at skabe særlige forestillinger om, hvad der er rigtigt og legitimt at gøre. En central opgave for forskere, ledere og den militære profession er kritisk at reflektere over, hvad vi åbner for eller afskærer os fra, når vi begriber militær ledelse på bestemte måder. Artiklens bredere analytiske pointe er et argument for, at hvis ledere, organisationer og professioner er bevidste om metaforers skabende kraft, kan de inddrage metaforer og bruge dem aktivt i deres udvikling. Artiklens metode og analytiske pointer rækker derved ud over det militære felt, idet vi foreslår, at man i princippet kan overføre den granskning, som vi her foretager med militær ledelse, til andre professioner og ledelsesområder.

\section{Oversigt over artiklen}

Artiklen er opbygget på følgende måde: Først skitserer vi ledelse som en central del af officersprofessionen. Herefter uddybes metaforperspektivet, og det beskrives, hvordan dette perspektiv forskyder iagttagelsesinteressen fra at ville finde essensen af noget til at ville undersøge den formative kraft, som ligger i forskellige metaforer. Denne formative kraft illustreres ved at læse 
Mintzbergs ledelsesmodel metaforisk og relatere den til begrebet militær ledelse. Afslutningsvis diskuteres metafortilgangen, og vi fremsætter forslag til, hvordan man kan arbejde med metaforer.

\section{B. Ledelse som del af officersprofessionen}

\section{Officersprofessionens mangfoldighed}

Officerer har en række forskelligartede opgaver: De leder soldater, de underviser, de udarbejder analyser for de militære styrelser og stabe, de leder og deltager i nationalt og internationalt stabsarbejde, de fungerer som projektledere, de kan være specialiserede som logistikere, piloter, skibschefer, efterretningsanalytikere, teknikere m.v. Selvom militær ledelse er en central del af officersvirket, dækker officersvirket altså over mere end ledelse.

\section{Debatten om officersuddannelserne og officersprofessionen}

Militær ledelse er et i flere henseender veludforsket fænomen. Alene i skandinavisk sammenhæng har militær ledelse været genstand for flere undersøgelser (Se f.eks. Barfod, 2017; Boe, 2015; Boe \& Bang, 2016; Holsting, 2017; Lundberg, Artéus, Wijnbladh, \& Försvarshögskolan, 1997; Nørgaard \& Holsting, 2014; Nørgaard, Holsting, \& Schultz-Larsen, 2015; Nørgaard, Holsting, \& Thorbjørnsen, 2008) $)^{\text {ii }}$. Af flere grunde står officersprofessionen i Danmark aktuelt i en situation, hvor drøftelser om dens optegning og organisering er centrale. Denne aktualisering er bl.a. ansporet af beslutningen i 2011 om at omkalfatre officersuddannelserne til militære diplomuddannelser samt oprette en Master i Militære Studier (MMS) ${ }^{\text {iii. }}$. Disse uddannelser gennemføres af Forsvarsakademiet og henhører nu under det ordinære videregående uddannelsessystem. Det betyder, at uddannelserne akkrediteres på samme vilkår som andre civile uddannelser, i modsætning til tidligere, hvor Forsvarets videregående uddannelser havde egne standarder. Officersprofessionen er samtidig præget af, at det militære ledelses- og chefvirke i de senere år har været debatteret, både som følge af denne ændring i uddannelsesstrukturen og efter forskellig kritik, der er fremkommet internt i Forsvaret såvel som i pressen (se f.eks. Arnfred, 2013; Borre, 2014; Rasmussen, 2018; Robl, 2012; Svendsen \& Bendtsen, 2016). Endelig hænger de aktuelle drøftelser om officersprofessionen sammen med den professionalisering af ledelsesfaget generelt, der har fundet sted i de senere år (se f.eks. Bévort, 2017; Hagedorn-Rasmussen, Krause-Jensen, \& Mogensen, 2017).

\section{Samspillet mellem ledelse og profession er sat til debat}

Den generelle professionalisering af ledelsesfaget har afstedkommet ændringer i måden, hvorpå relationen mellem ledelse og fagprofessioner anskues. I mange studier er relationen mellem ledelse og fagprofessioner blevet set som et modsætningsforhold, f.eks. mellem de fagprofessionelles ønske om autonomi og ledernes ønske om kontrol (Carvalho, 2012; Forrester, 2000; Kirkpatrick \& Ackroyd, 2003; Knudsen, Olesen, Bojesen, \& Gleerup, 2014). Hagedorn-Rasmussen et al. taler om, at 
ledelsens professionalisering indebærer, at ledelsen frigør sig fra de professioner, den skal lede (2017, s. 6), mens Bévort (2017) taler om et modsætningsforhold mellem ledelsen og den professionelle logik. Hvad angår til den militære ledelse viser relationen mellem ledelse og profession sig på en anden måde, idet ledelse ikke konstitueres som noget uden for officersprofessionen, men som en integreret del af officersprofessionen. Uddannelsen til officer betegnes som en lederuddannelse; det at være professionel officer indebærer, at man er leder fra starten af sin karriere. Dette gør relationen til lederrollen til et internt anliggende for officersprofessionen. Officeren og Forsvaret må derfor til stadighed reflektere over og udvikle ledelsesforståelsen i Forsvaret. Dette understreges bl.a. af Holsting (2017), som i sin historiske analyse af, hvordan de militære chefer retfærdiggør deres profession, peger på, at det militære chefvirke igennem tiden har undergået en løbende re-professionalisering. Denne reprofessionalisering forudsætter den militære chefs stadige kritiske refleksion og understreger behovet for kontinuerlig udvikling af professionen. Denne kritiske refleksion er ikke mindst nødvendig, fordi officeren dagligt må forholde sig til mangfoldige og ofte modstridende kvalitetskriterier for god ledelse (jf. Holsting, 2017, s. 170-171).

\section{Militær ledelse er som fænomen til stadig forhandling}

Ovennævnte forhold, mener vi, tydeliggør, at en fast definition af begrebet militær ledelse ikke på en meningsfuld måde kan indfange et så komplekst, dynamisk og kontekstafhængigt praksisfelt som militær ledelse. Militær ledelse er en polyfon størrelse, der udspiller sig i mange forskellige kontekster og situationer, og som til stadighed forhandles, udvikles og antager nye former og nuancer. Det er et fænomen, som kan anskues fra mange forskellige vinkler. Dermed følger vi Alvesson og Spicer, der skriver om ledelse:

"Understanding leadership involves acknowledging that any insights that we come up with will always be uncertain and preliminary. Eternal and robust truths are almost impossible to come by in a complex, situation-specific and dynamic area like leadership. All we can do is to expand the range of ways we can interpret leadership and hopefully provide some useful and engaging insights that we did not have before." (2011, s. 4)

Vores pointe er ikke relativistisk i den forstand, at det er ligegyldigt, hvordan vi taler om militær ledelse. Tværtimod er pointen, at det gør en stor forskel. Den måde, hvorpå vi former begrebet, åbner særlige mulighedsrum og lukker andre ved at skabe bestemte forestillinger om, hvad der er rigtigt og legitimt at gøre. Opgaven for forskere og ledere er derfor kritisk at reflektere over, hvad vi åbner for eller afskærer os fra, når vi taler om militær ledelse - eller andre typer af ledelse - på bestemte måder. 


\section{Metaforer som redskab til ledelses- og organisationsudvikling}

\section{Metaforer som metode i organisations- og ledelsesforskning}

I det følgende vil vi positionere artiklen i forhold til anden ledelses- og organisationsforskning, der tager metaforer som udgangspunkt. Vi vil udfolde den forståelse af metaforer, som artiklen gør gældende og i forlængelse heraf beskrive metaforarbejde som et værktøj for praksis.

Gareth Morgans bog Images of Organization fra 1986 var et af de første og mest signifikante bidrag i en bølge af organisationsforskning, som beskæftigede sig med metaforers anvendelse og betydning for organisationer (Se f.eks. Cornelissen, 2005; Cornelissen, Kafouros, \& Lock, 2005; Cornelissen, Oswick, Christensen, \& Phillips, 2008; Heracleous \& Jacobs, 2008; Jermier \& Forbes, 2011; Tohidian \& Rahimian, 2019; Örtenblad, Trehan, \& Putnam, 2017). Siden er metaforer anvendt inden for en lang række emner i organisationsforskningen, f.eks. inden for organisatorisk kommunikation (Putnam \& Boys, 2006), informationssystemer (Atkinson, 2003; Kendall \& Kendall, 1993), projekter (Winter \& Szczepanek, 2009), forandringsledelse (Marshak, 1993), social kapital (Andriessen \& Gubbins, 2009), køn (Carli \& Eagly, 2016; Kemp, 2016), og i særlig grad ledelse (Se f.eks. Alvesson \& Spicer, 2011; Amernic, Craig, \& Tourish, 2007; Linn, Sherman, \& Gill, 2007; Perreault, 1996; Ruth, 2014; Schechter, Shaked, Ganon-Shilon, \& Goldratt, 2016; Virtanen, 2017).

Cornelissen, Oswick, Christensen og Phillips (2008) nævner i deres overblik over studier, der omhandler metaforers betydning for organisering og arbejdsliv, tre forskellige tilgange til metaforer:

For det første er der studier inden for 'organizational behaviour', som empirisk afdækker og undersøger betydningen af de metaforer, der anvendes, f.eks. blandt medarbejdere eller ledere i en given organisation eller ledelsessammenhæng (se f.eks. Amernic et al., 2007; Kendall \& Kendall, 1993; Latusek \& Vlaar, 2015; Schechter et al., 2016; Smith \& Simmons, 1983).

For det andet er der studier, der beskæftiger sig med organisationsudvikling, og som arbejder med at støtte medarbejdere og ledere i at skabe og understøtte hensigtsmæssige metaforer. Her får metaforperspektivet en interventionistisk karakter (se f.eks. Barrett \& Cooperrider, 1990; Greve, 2016; Jacobs \& Heracleous, 2006; Marshak, 1993; Tsoukas, 1991; Winter \& Szczepanek, 2009).

Som en tredje tilgang nævner Cornelissen et al. den type studier, hvor metaforer udvikles med henblik på at støtte forskning og teoretisering (Andriessen \& Gubbins, 2009; se f.eks. Boxenbaum \& Rouleau, 2011; Cornelissen et al., 2005; Morgan, 1986; Schoeneborn, Vásquez, \& Cornelissen, 2016). I forhold til ovennævnte kategorier er vores udgangspunkt ikke empirisk at afdække de metaforer, der konkret er i spil f.eks. i Forsvarets ledelse eller blandt officerer i Forsvaret. Vi udvikler heller 
ikke nye metaforer for militær ledelse. I stedet bidrager vi til den interventionistiske tilgang ved at undersøge, hvilke praktiske implikationer metaforerne kunst, håndværk og videnskab hver især kan have, når de bruges som forståelsesrammer for militær ledelse. Endvidere undersøger vi hvordan aktuelle militærorganisatoriske og militærledelsesmæssige valg kan relateres til disse tre metaforer. Samtidig foreslår og illustrerer vi metaforarbejde som en metode, hvormed man generelt kan arbejde med udvikling af en profession.

\section{Metafor som perspektiv}

Morgan (1986) viste, hvor forskelligt en organisation kan tage sig ud, alt efter hvilke indforståede metaforer den forstås ud fra. Hans anvendelse af metaforer som analytiske redskaber til at forstå organisationer kan bl.a. ses i forlængelse af Schöns arbejde med metaforer, som udkom få år forinden (Schön, 1979). Schön foreslog betegnelsen "generativ metafor" som et begreb, der sætter fokus på metaforers funktion som iagttagelsesperspektiver, der bidrager til at skabe ny indsigt og forme praksis (1979). Dette perspektiv fremkom som et alternativ til den tidligere primært lingvistiske interesse i metaforen som en rent figurativ sprogkonstruktion (se f.eks. Black, 1962). Endvidere var Morgans metaforanvendelse i tråd med Lakoff \& Johnsons (1980) beskrivelse af, hvordan "hverdagens metaforer" strukturerer, hvordan vi tænker og handler.

Schön, Lakoff og Johnson og Morgan var alle optagede af metaforens evne til at forme blikket ved at overføre perspektiver eller rammer for iagttagelse fra ét område til et andet (Schön, 1993, s. 137).

"We use metaphor whenever we attempt to understand one element of an experience in terms of another. Thus, metaphor proceeds through implicit or explicit assertions that A is (or is like) B. When we say 'the man is a lion,' we use the image of a lion to draw attention to the lion-like aspects of the man." (Morgan, 2006, s. 4).

Når vi bruger løven som metafor for en mand, ser vi altså manden i et lys, der er farvet af vores forestillinger om løver. På den måde bliver løve perspektiv for mand.

I denne artikel forstår vi netop, i tråd med Schön, Lakoff og Johnson og Morgan, metaforer som

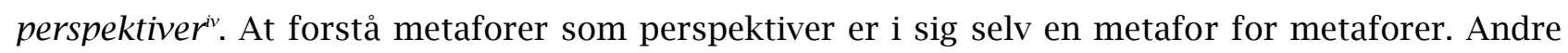
metaforer kunne være, at vi ser metaforer som illustrativt pynt, som retorisk værktøj eller som spejl af virkeligheden.

Når vi iagttager metaforer som perspektiver, bliver vi opmærksomme på særlige træk ved metaforer. Vi får f.eks. øje på, at metaforen som perspektiv både forenkler og fortegner. Den forenkler ved at betone noget særligt, hvilket gør billedet mere tydeligt, og den fortegner, idet dette tydeliggjorte 
billede samtidigt karikerer. Morgan har kaldt dette for metaforens paradoksale karakter (2006, s. 5, 2011, s. 463). Han gør opmærksom på, at metaforer både åbner og lukker for indsigt (2006, s. 4). Metaforbegrebet gør det dermed tydeligt, at vi ikke iagttager fra en privilegeret position, men altid er bundet af et perspektiv med en bestemt og afgrænset horisont. For perspektiver og metaforer gælder derfor, at udsyn og begrænsninger hænger sammen, eller, som Thyssen formulerer det, at "blindhed er en betingelse for at iagttage" (2000, s. 13). Det giver udsyn, når perspektivet indsætter tydelige forskelle i det myldrende kaos af støj, som udgør vores sanseindtryk. Hvis man f.eks. kigger efter initiativ blandt sine soldater, bliver ens opmærksomhed rettet mod dette og ikke mod alt muligt andet. Samtidig skaber perspektiver begrænsninger, fordi enhver forskel kunne have været en anden; man kunne f.eks. have kigget efter fysisk formåen.

Den forenkling, som metaforer tilbyder, er altså et vilkår for at se noget. Ifølge Lakoff og Johnson er metaforer således grundlæggende strukturerende for vores begrebssystem (1980, s. 3). Spicer og Alvesson pointerer ligeledes, hvordan metaforer må forstås som et alment vilkår for vores erkendelse (2011, s. 35).

Metaforen 'metafor som perspektiv' er parallel med Alvesson og Deetz' metafor for teorier. Alvesson og Deetz anbefaler for det første, at man bruger linsen som metafor, når man skal forstå teorier:

"In our view, theory is a way of seeing and thinking about the world rather than an abstract representation of it. As such it is better seen as the 'lens' one uses in observation than a 'mirror' of nature." (2000, s. 37)

Både teorier og metaforer forstås altså her som særlige blik på verden. For det andet mener Alvesson og Deetz, at det er et vilkår, at alle skabninger har teorier (2000, s. 39-40), ganske ligesom metaforer ses som et alment vilkår hos Lakoff og Johnson og Spicer og Alvesson.

I tråd med dette foreslår vi i denne artikel, at man udvider forståelsen af metaforer ved at sammenligne dem med den forståelse af teorier, som Alvesson og Deetz præsenterer.

\section{Teorier og metaforer forstået ved tre grundlæggende funktioner}

Alvesson og Deetz (2000, s. 41-46) foreslår, at man forstår teorier ved tre grundlæggende funktioner: De leder opmærksomhed, de organiserer erfaring, og de muliggør brugbare handlinger. Det samme kan siges om metaforer: Metaforer leder opmoerksomheden ved at tilbyde et bestemt udsyn, der både skaber en måde at se og en måde ikke at se (Morgan, 2017, s. xiv). Lakoff og Johnsons klassiske eksempel 'diskussion som krig' (1980) viser eksempelvis, at vi med netop dette blik får øje på diskussionens destruktive og antagonistiske karakter, men at vi også derved kan have svært ved at se dens samskabende potentiale. Metaforer organiserer erfaringen ved at tilbyde en 
særlig meningsstruktur, der forbinder og relaterer tingene på bestemte måder (Bousquet, 2009, s. 27). Ikke blot henleder metaforen opmærksomheden på særlige detaljer. Den binder også detaljerne sammen på en meningsfuld måde, og disse forbindelser medfører særlige antagelser om, hvordan tingene hænger sammen. På den måde vil det at forstå diskussioner som krige bidrage til at strukturere vores erfaringer med diskussioner på en særlig måde, hvor vi f.eks. husker vindere og tabere, angreb og forsvar. Samtidig medfører denne metafor særlige antagelser, f.eks. at andres dårlige argumentation er vores fordel. Metaforer medfører dermed også en særlig rettethed, der muliggør eller peger på bestemte handlinger, mens de skjuler andrev. Metaforen 'diskussion som krig' kan f.eks. lægge op til forsvar af egne synspunkter og angreb på andres, mens krigsmetaforen ikke skaber blik for muligheden for nysgerrig undersøgelse af andres synspunkter med henblik på at blive klogere. Ved at tale om diskussion som krig overfører vi med andre ord den normativitet, der ligger i krigsmetaforikken til diskussioner. ${ }^{\text {vi }}$ Den særlige rettethed, som enhver metafor medfører, påvirker altså ikke blot, hvad vi ser, men muliggør eller peger på bestemte handlinger, mens andres skjules. Metaforer gennemsyrer dermed ikke blot vores sprog, men tillige vores tanker og handlinger (Lakoff \& Johnson, 1980, s. 55). De har så at sige en præskriptiv tone (Morgan, 2006, s. 340).

På denne måde rummer enhver metafor sin egen måde at lede opmærksomheden, organisere erfaringen og foreskrive handlinger. Metaforer bliver fundamentale, idet ændringer af vores metaforer hænger sammen med ændringer af vores måder at tænke og handle på og omvendt. På baggrund af dette perspektiv på metaforer foreslår vi metaforarbejde som en produktiv tilgang til at reflektere over og udvikle begrebet militær ledelse.

\section{Metaforarbejde som refleksiv metode}

Metaforarbejde handler om at reflektere over, hvilke implicitte antagelser der ligger i de metaforer, vi anvender, og hvad disse antagelser betyder for det, som vi er optaget af. En central opmærksomhed i dette arbejde handler ganske enkelt om at tænke, at vi bruger metaforer. Vi er nemlig langt fra altid opmærksomme på vores brug af metaforer (jf. Lakoff \& Johnson, 1980). ${ }^{\text {vi }}$

Herunder vil vi opsummere nogle af de centrale pointer fra forståelsen af metaforer som perspektiver og give forslag til, hvilke opmærksomheder disse pointer kan give os i praksis.

1. Metaforer er et vilkår. Det handler derfor ikke om at eliminere metaforer, men om at være opmærksom på, hvilke der er i spil. Vi kan forstå diskussioner som andet end krig, men vi må forstå dem som noget. Alternative metaforer kunne f.eks. være 'diskussion som dans' eller 'diskussion som udforskning'.

2. Metaforer leder opmærksomheden, men indsigten fra en metafor er altid partiel. En metafor kan aldrig være dækkende, men vil altid være fortegnet som en karikatur, da 
noget trækkes frem, mens andet skubbes i baggrunden. Denne opmærksomhed kan få os til at spørge, hvad vi har overset, når vi anvender en bestemt metafor. Hvad gør krigsmetaforikken os f.eks. blinde for, når vi går til diskussioner? Hvilke andre metaforer ville kunne give os en anden indsigt i diskussioner og dermed åbne op for et nyt handlerepertoire?

3. Metaforer organiserer erfaringen ved at tilbyde en struktur eller et mønster, som gør det lettere at skabe mening. Men denne mening dikteres ikke af virkeligheden. Det er altså ikke diskussioner, der dikterer, at vi skal forstå dem som krig, men krig som metafor, der kan gøre, at vi forstår diskussioner som sådan. Det bliver oplagt at spørge, hvilke implicitte antagelser der følger med denne forståelse, ligesom vi kan spørge, hvilke mønstre og antagelser andre metaforer kunne tilbyde.

4. Metaforer har en skabende kraft. Metaforer er perspektiver, som skaber særlige mulighedsrum ved at forme opmærksomheder, forventninger og forestillinger, og som dermed lægger op til bestemte handlinger, mens andre bliver mindre oplagte. Vi kan derfor spørge, hvordan en metafor fungerer for os. Skaber den hensigtsmæssige sociale relationer og praksisser? Hvad ville der eksempelvis ske, hvis vi forstod diskussioner som udforskning?

I den følgende del af artiklen undersøger vi med militær ledelse som case hvilke implicitte antagelser, der ligger i metaforerne kunst, håndvoerk og videnskab, samt de performative potentialer, som disse tre metaforer hver især kan have.

\section{Ledelsesforståelse gennem metaforer: Militær ledelse som kunst, håndværk eller videnskab}

\section{Metaforer for krigsførelse og ledelse}

Inden for teorier om krigsførelse skelnes der ofte imellem 'military art' og 'military science' (se f.eks. Møller, 2013; Williams, 2017). Denne skelnen har ført til debat om, hvorvidt krigsførelse skal ses som en kunst eller en videnskab (se f.eks. Calhoun, 2011; Vego, 2012). Nogle mener, at nutidige militære uddannelser og ledelsesforståelser i for høj grad lægger vægt på krigsførelse som en videnskab, mens selve krigskunsten glemmes (se f.eks. Williams, 2017). Andre mener, at videnskabens bidrag ikke fylder nok i krigsførelsen (se f.eks. Gregor, 2010).

Det er imidlertid ikke blevet drøftet, hvordan kunst og videnskab fungerer, når de anskues som rammer for at iagttage den specifikke del af officersgerningen, der omhandler militær ledelse. Mintzberg $(2005,2009)$ har anvendt kunst og videnskab som kendetegnende for at forstå ledelse som et generelt fag; han tilføjer desuden håndværk som en tredje forståelsesramme. Mintzberg 
foreslår således at betragte ledelse som en kontekstuel og erfaringsbaseret praksis, der finder sted inden for et rum, hvis hjørner udgøres af tre poler: kunst, håndvoerk og videnskab (Mintzberg, 2009, s. 9-11. Se figur 1 nedenfor). Kunst forstår han som visioner, idéer, kreativitet og integration; håndværk som praktisk indlæring og anvendelse af erfaringer i deres relevante kontekst; og videnskab, mener han, tilbyder struktur og mening gennem systematisk analyse af erfaring, iagttagelse og viden (Mintzberg, 2009).

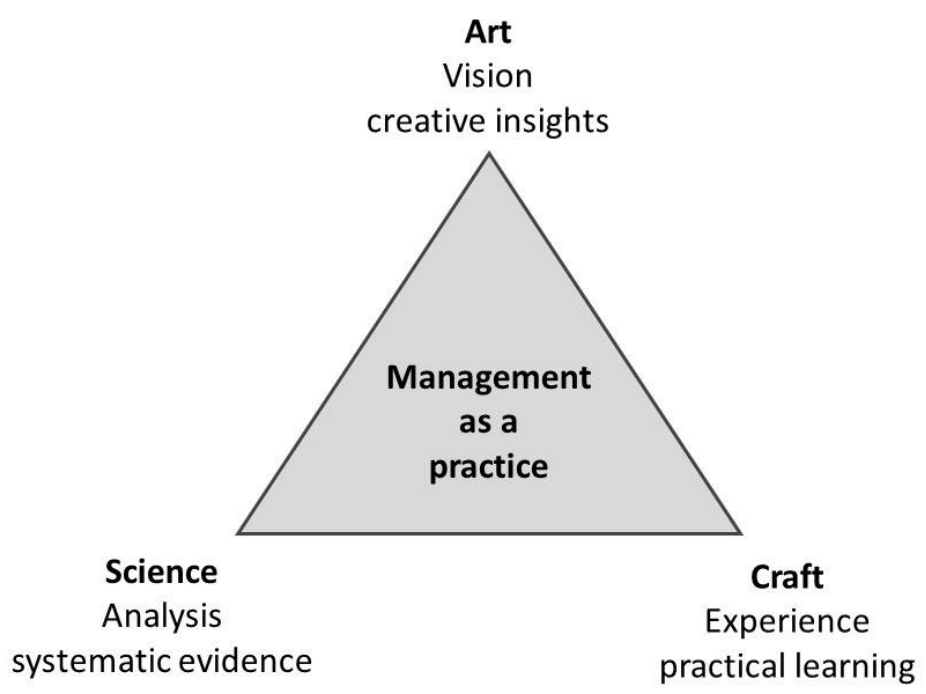

Figur 1. Management som kunst, håndvaerk og videnskab (kilde: Mintzberg, 2009, s. 11)

Når vi har valgt Mintzbergs ledelsesmodel som udgangspunkt for vores konkrete analyse, skyldes det for det første, at Mintzbergs poler ligger tæt op ad metaforer, som allerede gør sig gældende inden for teorier om krigsførelse. Kunst- og videnskabsmetaforerne udgør som nævnt en velkendt dikotomi inden for den militærfaglige litteratur, og også håndværksmetaforen ses anvendt af officerer i hverdagssammenhænge om officersgerningen (se f.eks. Hovedorganisationen af Officerer i Danmark, 2017; Lund, 2017). For det andet er Mintzberg ikke kun optaget af ledelsesgerningen, men også af uddannelsen af ledere. Dette er som nævnt relevant i forhold til Forsvarets aktuelle omkalfatring af sine lederuddannelser. Endelig er Mintzbergs empirisk funderede ledelsesteorier formentlig blandt de mest kanoniserede inden for ledelsesfaget.

Mintzberg ser kunst, håndværk og videnskab som tre ledelsesstile, hvor den effektive ledelse er den balancerede kombination af de tre (2005, s. 92-95, 2009, kapitel 4). Vi udforsker i det følgende, hvad der sker, hvis man arbejder med dem som tre forskellige metaforer, hvis blik hver især former militær ledelse på særlige måder, jf. tabel 1 . 
Vi har konstrueret metaforerne for kunst, håndværk og videnskab med udgangspunkt i Mintzbergs fremstilling af begreberne $(2005,2009)$ samt Tong og Bowling, der bruger begreberne i forhold til professionalisering af politiefterforskning (2006). Både Mintzbergs samt Tong og Bowlings fremstillinger er relativt kortfattede, derfor elaborerer vi de tre metaforer for at tydeliggøre, hvad de hver især skaber. Metaforerne i denne tekst er altså vores fremstillinger, idet vi har været optaget af, at de skulle være genkendelige i den militære kontekst. Dette studie kan imidlertid ikke konkludere, at de tre metaforer kommer til udtryk på præcis denne måde i Forsvaret. ${ }^{\text {vii }}$ I denne artikel har formålet blot været at fremstille de tre metaforer på en måde, som kan være produktiv for at forstå militær ledelse. Vi anvender de tre metaforer som idealtyper, hvilket vil sige, at vi udvælger og sætter fokus på bestemte stereotype og karakteristiske træk ved hver enkelt metafor. De fremstår altså næppe lige så rendyrkede i konkrete erfaringer, men er opstillet som begrebsmæssige redskaber med henblik på at få dem og det mulighedsrum, som de former, til at fremstå mere klart. Det skal understreges, at de tre metaforer ikke ses som dækkende for alle forståelser af begrebet militær ledelse. Pointen er, at der i brugen af dem ligger det moment, at de hver især fremhæver noget og skubber noget andet i baggrunden.

Da anledningen til artiklen blandt andet har været den debat om officersprofessionen i Danmark, som omstruktureringen og akkrediteringen af officersuddannelserne har givet anledning til, vil vi i det følgende særligt være optaget af, hvad metaforerne kunst, håndværk og videnskab hver især fremhæver i forhold til:

1. Forestillingen om den gode ledelsesudøvelse, dvs. vurderingskriterierne.

2. De organisatoriske processer, der understøtter udviklingen af en militær leder.

\section{Militær ledelse som kunst}

Når militær ledelse anskues som kunst, betones de unikke, kreative, visionære og intuitive aspekter af ledelse (Mintzberg, 2005, 2009). Denne metafor retter opmærksomheden mod den enkeltes genialitet, og praktisering af kunsten bliver en indre proces, der ikke kan gøres transparent (Tong \& Bowling, 2006, s. 325). Militær ledelse som kunst sætter dermed fokus på den enkelte leders personlighed og talent. F.eks. kan metaforen militor ledelse som kunst iscenesætte en forestilling om en særlig taktisk eller strategisk fornemmelse eller intuition, samt en unik karisma hos visse militære ledere.

Dette perspektiv har implikationer for måden at anskue ledelsesudøvelsen på. Betragtet som en kunstner skal lederen have frie hænder, så han eller hun kan få rum til at bringe sit eget intuitive bidrag i spil. Ledelsesprocesserne kan derfor ikke ekspliciteres eller sættes på formel, fordi de ses som opstående i det enkelte møde mellem situation, kontekst og den unikke leder. Man kan sige, at 
der opstår en vis mystik omkring ledelsesprocesserne. Vurderingen af ledelsesudøvelsen bliver ligeledes en subjektiv, æstetisk dom: kan lide eller kan ikke lide.

Kunstmetaforens forståelse af den militære leder kan have stor betydning for forestillingen om, hvad man som organisation skal gøre for at skabe en leder. Når lederen er kunstner, knyttes ledelsesegenskaber ofte til en forståelse af noget iboende. Dermed kan organisationen måske nok raffinere og støtte op om ledernes egenskaber, men disse bliver samtidig vanskelige at undervise $i$, fordi de udspringer af noget indre i personen, til den enkeltes talent. Fokus kan i stedet blive at finde, udvælge og dyrke de 'rigtige' personer, det vil sige dem, som på forhånd besidder særlige karakteristika, evner og personlighed.

Når ledelse anskues som kunst, kan det således understøtte prioriteringen af ledelsesuddannelsesforløb, der sætter fokus på individet. Dette kan ske både i udvælgelsesprocessen, som f.eks. kan lægge vægt på individuelle tests, og det kan ske undervejs i undervisningen, som f.eks. kan rumme tilbud om individuel coaching og personlig sparring. Det kan også ske på kurser, hvor udvalgte, 'talentfulde' kursusdeltagere får særlige muligheder for at øve sig i ledelseskunsten. Disse elementer findes i flere dele af Forsvarets lederuddannelser, ligesom vi kan genkende kunstmetaforen i Forsvarets koncept for 'talent management', hvor der - som i kunstmetaforens optik - er fokus på det iboende potentiale hos den enkelte:

"Et talent er en medarbejder, som på baggrund af sin personlighed, herunder evne og vilje, og stor faglighed udviser fremragende præstationer, og som vurderes at have vilje og potentiale til at udvikle sig hurtigere end gennemsnittet." ${ }^{\text {ix }}$

Lad os tage det militæroperative stabsarbejde som eksempel og se på, hvad det kan betyde for dette stabsarbejde, hvis militær ledelse anskues som kunst: I det operative stabsarbejde anvender den militære stab procedurer, metodikker og analysemodeller fra reglementer til at analysere komplekse taktiske og operative problemstillinger med henblik på at finde løsningsforslag. I kunstmetaforens perspektiv vil der i stabsarbejdet skulle etableres et mulighedsrum, hvor den militære leder selvstændigt og aktivt kan tolke, omformulere og måske endda sprænge rammerne og således bevæge sig uden for den fastlagte metodik. Dette mulighedsrum kan bl.a. ses understøttet af det militære begreb 'mission command' (se f.eks. Shamir, 2011; U.S. Department of the Army, 2014), som også anses for at være et centralt ledelsesprincip i det danske forsvar. 'Mission command' indebærer, at den militære leder modtager en klart defineret intention, styrkesammensætning og tidsramme, men i vidt omfang får frie hænder til at bestemme, hvordan han eller hun vil opnå denne intention. 


\section{Militær ledelse som håndværk}

Når militær ledelse anskues med håndværksmetaforen, betones praktisk erfaring og læring på jobbet (Mintzberg, 2005, 2009; Tong \& Bowling, 2006). Det handler om den enkelte leders erfaring, færdigheder og praktiske omsætning af disse, idet der er fokus på anvendelighed og nytte (Mintzberg, 2005, s. 93). Det bliver vigtigt at mestre teknikker og levere resultater.

I ledelsesudøvelsen forstået som håndværk omdannes procedurer og rutinemæssige måder at agere på til tavs, ofte kropsligt indlejret, viden og færdigheder (se f.eks. Heltberg \& Jellesmark, 2017). Modsat lederen som kunstner, som forventes at skabe noget nyt, der er formet af lederens person, skal den militære leder som håndværker gøre det samme - det samme som mester, eller det, som reglementerne og procedurerne foreskriver. Vurderingskriterierne vil have fokus på, om ledelsen mestrer teknikker, værktøjer og procedurer, og om der skabes gedigne og solide produkter. Som sådan medfører håndværksmetaforen et pragmatisk perspektiv, hvor værktøjer og procedurer løbende justeres ud fra erfaringer med, hvordan de fungerer; virker de?

Set som et håndværk bliver militær ledelse en praksis, som man tilegner sig ved at gøre den; f.eks. ved at iagttage den ledelse, der udøves, ved at stille spørgsmål til mere erfarne militære ledere og ved selv at lede militære operationer eller lede i andre relevante kontekster. Hvad angår skabelsen og den løbende udvikling af militære ledere, kan forståelsen af militær ledelse som et håndværk lægge op til, at læring og udførelse støtter sig til procedurer og doktriner, ligesom læring om store 'mestre' - militære førere og chefer gennem tiden - kan vægtes højt, således at deres erfaringer kanoniseres. Håndværksmetaforen implicerer, at ledernes erhvervelse af praktiske erfaringer betragtes som afgørende. Derved kan denne forståelse legitimere, at ledelsesundervisningen på alle niveauer gøres så praksisnær som muligt, ligesom den kan underbygge prioriteringen af strukturer, som støtter op om erfaringsdeling. Hvor kunstmetaforen har større fokus på den individuelle udvikling og maksimering af de udvalgte talenter, understøtter håndværksmetaforen i højere grad mere fællesorienterede tiltag såsom sidemandsoplæring, mesterlære og udvikling af ensartede standarder og retningslinjer for ledelsesudøvelsen. Dette syn på militær ledelse ses afspejlet i den praksisbaserede del af Forsvarets militære lederuddannelser. Her gennemføres en stor del af uddannelsesaktiviteterne som praksislæring, f.eks. i form af øvelser, hvor man til stadighed får mulighed for at øve sig i ledelseshåndværket. Endvidere er grundlaget for oplæringen i militær ledelse i vid udstrækning handlingsanvisende: Doktriner, reglementer, 'Standard Operating Procedures', regulativer og andre handlingsmanualer forefindes inden for mange grene af de militære ledelsesområder og på alle niveauer.

I eksemplet med det operative stabsarbejde handler ledelse set som håndværk om at sikre, at stabsmetodik og analysemodel mestres, og at doktrinen følges - eller udvikles på baggrund af en vurdering af, hvad der fungerer godt i praksis. Alt sammen med henblik på at levere et gedigent 
produkt. Denne tilgang genkendes delvist i militærets arbejde med "lessons identified / lessons learned", hvor formålet netop er at bruge erfaringer til at udvikle fremgangsmåder. Her kan den bagvedliggende metafor dog også være videnskab, afhængigt af hvordan dette arbejde med erfaringsopsamling foregår: Jo større grad af systematik, metodisk transparens og refleksion dette arbejde indebærer, desto mere har videnskabsmetaforen fået overtaget.

\section{Militær ledelse som videnskab}

Videnskabsmetaforen betoner systematik, analyse og tænkning (Mintzberg, 2005, 2009). Hvor kunstmetaforen betoner personligheden og håndværksmetaforen færdighederne, betoner videnskabsmetaforen snarere metodikken (Tong \& Bowling, 2006). Når militær ledelse anskues som en videnskab, vurderes det, at anvendelsen af teoretisk viden og videnskabelige metoder til at iagttage praksis kan styrke den militære ledelsesgerning.

Ledelsesprocesserne bliver herved hverken mystiske som i kunstmetaforen eller rutinemæssige og eventuelt tavse som i håndværksmetaforen. Tværtimod er der fokus på vigtigheden af andenordensiagttagelse - dvs. den militære leders og den militære organisations evne til at iagttage og forholde sig kritisk og refleksivt til egen praksis og egne antagelser. Lederen skal kunne eksplicitere, hvad han eller hun gør og hvorfor, således at valg og metoder kan granskes, drøftes og vurderes af fagfæller. Vurderingskriterierne handler om systematik, stringens, refleksionsniveau og transparens.

I forhold til den militære lederuddannelse kan en implikation af at anskue militær ledelse som videnskab være den prioritering af teoretiske redskaber og betoning af teoretiske aspekter af ledelse, som bl.a. ses i flere af de fag, der findes på Forsvarsakademiets uddannelser i dag. Ligeledes kan man sige, at akkrediteringen af Forsvarets uddannelser, der har medført større tilknytning af forskning og vægt på officerens analytiske og metodiske kapacitet, kobler sig til videnskabsmetaforen. Endelig bemærkes det, at denne artikel i sig selv kan ses som et bidrag til den udvikling af militær ledelse, der er baseret på videnskabsmetaforen.

Tager vi det førnævnte eksempel med det militære stabsarbejde, vil videnskabsperspektivet indebære, at anvendelse af stabsmetodikker og analysemodeller efterfølges af systematisk refleksion over disse. Endvidere skal metodikker og modeller løbende udvikles på baggrund af empiriske undersøgelser og teori. I dette perspektiv kan man således se de analytiske processer og aktuelt også militærfaglig forskning - som fundamentale og definerende for det militære arbejde og dermed som en del af den militære kernefaglighed. 


\begin{tabular}{|c|c|c|c|}
\hline & Kunst & Håndværk & Videnskab \\
\hline Karakteristika og ontologi & $\begin{array}{l}\text { Subjektivitet, det } \\
\text { intuitive, iboende, } \\
\text { emotionelle }\end{array}$ & Praktisk & $\begin{array}{l}\text { Objektivitet, } \\
\text { refleksivitet }\end{array}$ \\
\hline Vurderings-kriterier & $\begin{array}{l}\text { Estetik, kan } \\
\text { lide/kan ikke lide }\end{array}$ & $\begin{array}{l}\text { Virker det? Er det } \\
\text { holdbart? Gedigent? }\end{array}$ & $\begin{array}{l}\text { Er det baseret på solid } \\
\text { viden? Er processen } \\
\text { tydelig og begrundet? }\end{array}$ \\
\hline Proces & $\begin{array}{l}\text { Håndværket er } \\
\text { alene et middel. Det } \\
\text { er noget andet, der } \\
\text { er i } \\
\text { fokus. Processen } \\
\text { forudsætter, at } \\
\text { kunstneren gør } \\
\text { noget andet, noget } \\
\text { unikt. }\end{array}$ & $\begin{array}{l}\text { Transformerer } \\
\text { fremgangsmåder/ } \\
\text { procedurer til tavs } \\
\text { viden. Processen } \\
\text { forudsætter, at } \\
\text { håndværkeren } \\
\text { gør det samme (som } \\
\text { f.eks. mester). Brug } \\
\text { af værktøj, } \\
\text { doktriner mv. }\end{array}$ & $\begin{array}{l}\text { Transparens. } \\
\text { Processen forudsætter, } \\
\text { at lederen gør det helt } \\
\text { klart, hvad han eller } \\
\text { hun gør og hvorfor. } \\
\text { Metoder bedømmes og } \\
\text { accepteres gennem } \\
\text { fagfælle-bedømmelse. }\end{array}$ \\
\hline Eksplicitet om proces & $\begin{array}{l}\text { Kunstneren skaber } \\
\text { mystik om } \\
\text { processen, der ikke } \\
\text { kan ekspliciteres. }\end{array}$ & $\begin{array}{l}\text { Udelukker ikke, at } \\
\text { processen } \\
\text { ekspliciteres og } \\
\text { formaliseres. }\end{array}$ & $\begin{array}{l}\text { Kræver, at processen } \\
\text { ekspliciteres. }\end{array}$ \\
\hline Erfarings-opsamling & $\begin{array}{l}\text { Det er en dyd at } \\
\text { bryde med tidligere } \\
\text { erfaringer og } \\
\text { rutiner. }\end{array}$ & $\begin{array}{l}\text { Erfaringsopsamling } \\
\text { er centralt i forhold } \\
\text { til at fastholde } \\
\text { organisationens } \\
\text { kompetencer. }\end{array}$ & $\begin{array}{l}\text { Erfaringer } \\
\text { transformeres gennem } \\
\text { analyse og refleksion } \\
\text { med henblik på at } \\
\text { udvikle ny viden og } \\
\text { praksis. }\end{array}$ \\
\hline Lederskabelse & $\begin{array}{l}\text { Udvælge de rigtige } \\
\text { med talent og skabe } \\
\text { rammebetingelser, } \\
\text { der giver passende } \\
\text { frihed til } \\
\text { improvisation og } \\
\text { inspiration. }\end{array}$ & $\begin{array}{l}\text { Læring af } \\
\text { procedurer og } \\
\text { fremgangsmåder, } \\
\text { mesterlære, } \\
\text { erfaringsdeling. }\end{array}$ & $\begin{array}{l}\text { Teori anvendes til } \\
\text { refleksion over og } \\
\text { iagttagelse af praksis }\end{array}$ \\
\hline
\end{tabular}

Tabel 1. Oversigt over de tre metaforer og deres optegninger af ledelsesrummet 


\section{Hvad de tre metaforer nedtoner}

Ovenfor har vi gennemgået, hvordan hver af de tre metaforer tilbyder en særlig opmærksomhed rettet mod forskellige aspekter af begrebet militær ledelse. Denne opmærksomhed betyder imidlertid også, at andre aspekter nedtones.

- Om kunstmetaforen kan man sige, at den ikke $i$ sig selv opfordrer til øget professionalisering af de militære ledelsesfag. Ledelse anskuet som kunst - som noget, der bliver til i unikke og inspirerede kreative processer - kan være vanskelig at forene med en forståelse af militær ledelse som en profession, der er kendetegnet ved faglige normer og standarder, og hvis udøvere har en bestemt formel uddannelse og arbejder efter en professionel etik. Fordi ledelse som kunst betoner den enkelte leders personlighed og unikke blik, kan kunstmetaforen ses at udfordre idéen om, at vi kan arbejde med koncepter for erfaringsopsamling, som ellers er centrale i den militæroperative praksis. Kunstmetaforen individualiserer forståelsen af ledelse og fokuserer på lederen som person. Dermed er der mindre blik for betydningen af kontekst og relationer. Metaforen kan lede til idoldyrkelse, samt til tidlige til- og fravalg af, hvem der betragtes som mulige talenter. Skarpt sat op kan man sige, at den fælles indsats står i skyggen af den individuelle helt; praktikeren nedvurderes i forhold til den geniale strateg, og den refleksive analytiker menes at stå i vejen for den kreative og intuitive skaber.

- I håndværksmetaforen ligger der ikke umiddelbart en tilskyndelse til andenordensrefleksion. Idet håndværksmetaforen betoner erfaring og tradition, kan der være risiko for, at professionen i dette perspektiv lukker sig om sig selv og skærmer sig mod anderledes input fra omverdenen (jf. Mintzberg, 2009). Ligeledes kan håndværksmetaforen stå i vejen for organisationens understøttelse af innovation og nytænkning, da metaforen kanoniserer erfaringer fra de store mestre og dyrker rutiner. Fremhævelsen af den praktiske håndværker kan skygge både for den idérige og visionære leder og for den refleksive analytiker, som begge kan tilbyde et større udsyn.

- Risikoen for, at professionen lukker sig om sig selv, er mindre i forbindelse med videnskabsmetaforen, som i højere grad rummer en tilskyndelse til at hente inspiration udefra og til at dele iagttagelser og refleksioner med andre fagfelter (jf. Mintzberg, 2009). Til gengæld nedtones de praktiske udøvelsesaspekter, og intuition som basis for beslutninger bliver illegitim. Den dybfølte mavefornemmelse fortrænges af den reflekterede analyse. Når videnskabsmetaforen bliver dominerende, kan tidskrævende metodisk analyse og refleksion tilsidesætte muligheden for at træffe beslutninger på kort 
tid og handle hurtigt. Dette kan underminere den for militæret helt centrale evne til at opretholde tempo og initiativ.

På denne måde optegner og afgrænser hver af de tre metaforer et særligt mulighedsrum for militær ledelse. En vigtig del af officerens professionelle virke og udvikling er derfor at reflektere over de mulighedsrum, som forskellige metaforer skaber. Bévort foreslår, at man kan forstå professionalisme som refleksion over "de kontekstuelle begransninger og det mulighedsrum, faget er underlagt" (2017, s. 41). Bévort fremhæver for ledelsesfaget de begrænsninger og mulighedsrum der er givet af "den konkrete organisation og dens omgivelser" (2017, s. 41). I nærværende artikel foreslår vi, at denne refleksion udvides til også at gælde det mulighedsrum, som formes af ledelsesfagets - eller det pågældende fags - egne metaforiske selvforståelser.

\section{E. Diskussion: Så hvilket perspektiv skal vi vælge?}

\section{Nye spørgsmål, som metaforperspektivet kan rejse}

En af de centrale forståelser i metaforarbejde er, at metaforer hverken kan eller har intention om i sig selv at være dækkende. Metaforer accentuerer nogle aspekter af et fænomen og skygger for andre. Eksempelvis var en af Mintzbergs primære hensigter at gøre op med det ret ensidige billede af ledelse som videnskab, som han mente, at MBA-programmerne typisk opererer med (Mintzberg, 2005). Metaforen rummer altså en iboende simplificering. Lige så vel som metaforer - og ikke mindst mangfoldigheder af metaforer - kan udvide vores forståelse for og indblik i fænomener, kan en metafor således også i sig selv i sin énsidethed virke til at begrænse vores evner til at begribe især komplekse fænomener. Endvidere er det væsentligt at være opmærksom på, at metaforer er sociale konstruktioner og derfor fortolkes forskelligt. Hvad nu hvis vi eksempelvis i denne artikel havde valgt at se kunstneriske processer som først og fremmest en kollektiv proces? Opmærksomheden på disse begrænsninger er en del af det metaforarbejde, som vi foreslår, og kan samtidig gøre os reflekterende over, hvilke grænser der mon kan være for metaforens bidrag til forståelse af komplekse fænomener.

I denne artikel har vi undersøgt, hvordan vores metaforer for militær ledelse og den militære leder, kan påvirke vores måde at vurdere og udvikle militær ledelse. Med baggrund i metaforerne kunst, håndværk og videnskab som redskaber kan vi rejse mange andre spørgsmål, som kan give blik for de rationaler, der ligger bag fremførte synspunkter. Er nogle metaforer f.eks. mere fremherskende end andre inden for bestemte områder eller praksisser - i militæret f.eks. inden for føring i kamp over for det militære stabsarbejde? Eller er der mon forskel på de metaforer, som f.eks. knyttes til henholdsvis officersgruppen, sergentgruppen og konstabelgruppen? Og hvilke betydninger får dette for måden, hvorpå man i Forsvaret taler sammen og samarbejder om ledelse? Vi kan også bringe 
andre metaforer i spil end de tre, der er gennemgået i denne artikel. Ved at anvende en mangfoldighed af metaforer bidrages der til en nuancering af forståelsen af militær ledelse. Metaforarbejde kan skabe bevidsthed og muliggøre dialog om, hvilke metaforer og grundlæggende antagelser vi læner os op ad i vores forventninger og argumenter. Dermed kan antagonistiske debatter, hvor valget bliver enten-eller, bedre undgås, og et nuanceret og rigere både-og muliggøres.

\section{Forslag til, hvordan man kan arbejde med metaforer i praksis}

Et væsentligt spørgsmål er på denne baggrund, om der er måder, hvorpå professioner og organisationer - som eksempelvis officersprofessionen og Forsvaret - kan støtte op om arbejdet med metaforer som et redskab til selvudvikling. Nedenfor fremsættes tre forslag, som også vurderes at kunne overføres til andre ledelsessammenhænge med udgangspunkt i disses specifikke kontekst:

1. For det første foreslås det, at alle medlemmer af en profession eller en organisation kan få noget ud af at forholde sig nysgerrigt og undersøgende til professionens eller organisationens egne metaforiske grundbegreber; det vil sige til de metaforer og perspektiver, der bringes i spil i professionens eller organisationens selvforståelse. I forhold til denne artikels genstandsfelt vil dette være ensbetydende med et forslag om, at alle i Forsvaret kan få noget ud af at forholde sig nysgerrigt og undersøgende til de metaforer, der bringes i spil i forståelsen af den militære ledelse. Nærværende artikel bygger som tidligere nævnt ikke på en empirisk analyse af, hvorledes militæret i dag (eller historisk) selv taler om ledelse. Hvis vi kigger på nyere tids udvikling i forhold til hvilke værdier og vurderingskriterier, som militære ledere selv lægger vægt på (cf. Holsting 2017), kan vi dog formode, at de centrale metaforer, der inden for militæret knyttes til den militære leder og den militære ledelse, ligeledes har undergået en udvikling.

2. For det andet foreslås det, at professioner og organisationer med fordel kan undersøge, hvilke eksisterende og hvilke nye metaforer, der kan understøtte professionens eller organisationens medlemmer i deres arbejde ${ }^{\mathrm{x}}$. I Forsvaret vil dette betyde en undersøgelse af, hvilke eksisterende og hvilke nye metaforer der kan understøtte den militære leder i sit virke i nutidige og fremtidige operationer og operationskontekster. Dvs. en undersøgelse af, hvordan forskellige metaforer og perspektiver kan berige forståelsen af militær ledelse og dermed også nuancere og kvalificere uddannelse, træning og kompetenceudvikling af militære ledere.

3. For det tredje foreslås det, at man arbejder med at gøre det enkelte professionsmedlem mere bevidst om, hvilke metaforer han eller hun anvender til at forstå og udøve sin profession. I relation til denne artikel vil det handle om at gøre den enkelte militære leder mere bevidst om, hvilke metaforer han eller hun bruger til at forstå og udøve sin egen 
militære ledelse. Denne indsats kan ikke mindst styrkes i alle dele af det arbejde, som vedrører uddannelse.

Selv om vi med disse forslag fokuserer på refleksion, nysgerrighed og en undersøgende indstilling - hvilket knytter sig til videnskabsmetaforen - må det ikke skygge for vigtige pointer fra de to andre metaforer. I relation til håndværksmetaforen har Bøhn og Thomsen (2017) vist, at den refleksive tilgang ikke er tilstrækkelig i uddannelsen af indsatsledere. De plæderer derfor for en mere praksisnær træning. Sådanne anbefalinger, som knytter sig mere til håndværksmetaforen, kan overføres til flere dele af officersvirket, f.eks. til situationer, hvor officeren virker som operativ fører. Her er simulationer og øvelser vigtige elementer i uddannelsen. Tilsvarende er den militæroperative føringsvirksomhed i vid udstrækning baseret på entydige handlingsanvisninger. Set fra håndværksmetaforen kan en indvending mod denne artikels ærinde derfor kunne lyde, at militære ledere snarere har brug for klare definitioner og opskrifter på god ledelse end for andenordensiagttagelser og metaforarbejde. I interne drøftelser af akkrediteringen af Forsvarets lederuddannelser ses det da også, at ikke alle tilslutter sig disse uddannelsers tilnærmelse til akademia (Se f.eks. Clemmesen, 2015; Hovedorganisationen af Officerer i Danmark, 2017). Man frygter bl.a., at akkrediteringskravene og de tiltag, som disse medfører, kan gå ud over uddannelsernes relevans for praksis ["[D]et bør kraftigt overvejes, om akkrediteringen koster på professionalismen - det militære håndværk - og måske endda er kontraproduktiv" (Hovedorganisationen af Officerer i Danmark, 2017, s. 33).

Indvendinger som disse viser, at forslag til uddannelsen af militære ledere, som baserer sig på videnskabsmetaforen, er nødt til at forholde sig til relevansen for praksis. Derfor afsluttes diskussionen her med overvejelser om metaforarbejdets praktiske relevans.

\section{Relevansen af metaforarbejde}

Vi knytter her an til Latusek og Vlaar's pointe om, at arbejdet med metaforer kan være en måde at forbinde teori og forskning med praktisk relevans (2015), og foreslår, at metaforer kan spille en rolle i udviklingen af militære ledere. Vi har vist, hvordan metaforarbejde både kan være en akademisk disciplin, der trækker på forskningsbaserede teorier og kan være en praktisk relevant metode for den militære leder såvel som for den militære organisation. Artiklens sigte har derfor ikke alene været at undersøge implikationer af bestemte metaforer for militær ledelse, men også at skitsere og anbefale metaforarbejde som en måde at arbejde med den kontinuerlige udvikling af officersprofessionen.

Dette betyder dog ikke, at artiklen giver opskrifter på handling. Relevans skal i denne sammenhæng forstås i en mere refleksiv henseende, hvor målet er at berige forståelsen af militær ledelse. Dermed knytter vi an til en konceptuel tilgang til relevans, hvor præmissen er, at forskning kan være relevant 
for praksis ved at tilbyde sproglige begreber, der har potentiale til at "change the way we think and communicate about our world and, by extension, about our decision situations" (Nicolai \& Seidl, 2010, s. 1267). Styrken ved en sådan tilgang er, at den ikke alene tilbyder hjælp til at løse de problemstillinger, vi allerede forstår, men også giver os nye måder at forstå problemstillinger på, hvilket giver blik for nye handlemuligheder.

\section{F. Konklusion}

Når ledelse udgør en integreret del af officersprofessionen, og militær ledelse vedvarende debatteres både inden for og uden for Forsvaret, bliver officerens evne til at forholde sig refleksivt til ledelsesvirket en central del af den professionelle udvikling. Artiklens centrale pointe er, at metaforarbejde kan understøtte en sådan tilgang.

Artiklen har undersøgt, hvordan tre ledelsesmetaforer - kunst, håndværk og videnskab - kan forme militær ledelse og den organisering, der støtter op herom. Vi har vist, hvordan de tre metaforer får betydning for praksis i Forsvaret, idet de hver især instituerer bestemte opmærksomheder, forventninger og forestillinger. Vurderingen og udviklingen af militær ledelse formes på forskellige måder, afhængigt af hvilken metafor der lægges til grund. Hver metafor skaber et særligt udsyn og samtidig en særlig blindhed, og hver metafor fremhæver bestemte idealer, mens andre samtidig sættes i skyggen. Det, der fremstår som en dyd i lyset af én metafor, dadles i lyset af en anden. Når der i en profession eller organisation er forskellige metaforer i spil, som i nogle henseender udelukker eller modarbejder hinanden, kan det give anledning til misforståelser og konflikter. Hvis man er opmærksom på dette vilkår, kan man vende det til et produktivt mulighedsrum for professionens eller organisationens løbende udvikling.

En central pointe i artiklen er, at en fast og entydig definition ikke yder begrebet militær ledelse retfærdighed. Det betyder imidlertid ikke, at vi anbefaler, at man afholder sig fra at prøve at forstå og beskrive militær ledelse; tværtimod anbefaler vi, at man netop ser det som et kontinuerligt arbejde at følge og undersøge det foranderlige og flertydige fænomen, som kaldes militær ledelse. I samme åndedrag anbefaler vi, at enhver beskrivelse, forståelse eller definition af militær ledelse ledsages af en kritisk andenordensbetragtning af denne beskrivelses performative potentialer: Hvad gør den opmærksom på? Hvad er den blind for?

Vores undersøgelse af metaforers betydning for, hvad militær ledelse bliver til, kan gennemføres på samme måde inden for andre professioner og ledelsesområder. Vi har vist, at de metaforer, som vi tager for givet, både strukturerer vores måder at tænke og handle på. Det gør metaforarbejde, som skitseret i denne artikel, til et centralt redskab til udvikling af professioner og organisationer. 


\section{Referenceliste}

Alvesson, M., \& Deetz, S. (2000). Doing critical management research. London; Thousand Oaks, Calif: Sage Publications.

Alvesson, M., \& Spicer, A. (Red.). (2011). Metaphors we lead by: Understanding leadership in the real world. Routledge.

Amernic, J., Craig, R., \& Tourish, D. (2007). The transformational leader as pedagogue, physician, architect, commander, and saint: Five root metaphors in Jack Welch's letters to stockholders of General Electric. Human Relations, 60(12), 1839-1872.

https://doi.org/10.1177/0018726707084916

Andriessen, D., \& Gubbins, C. (2009). Metaphor Analysis as an Approach for Exploring Theoretical Concepts: The Case of Social Capital. Organization Studies, 30(8), 845-863.

https://doi.org/10.1177/0170840609334952

Arnfred, C. E. (2013, september 28). Hækkerup: Illoyale oberst Hachel-typer skader forsvaret. Berlingske. Hentet fra https://www.b.dk/content/item/485491

Atkinson, C. J. (2003). The Nature and Role of Generative Systemic Metaphor within Information Systems Planning and Development. I E. H. Wynn, E. A. Whitley, M. D. Myers, \& J. I. DeGross (Red.), Global and Organizational Discourse about Information Technology (Bd. 110, s. 323-343). https://doi.org/10.1007/978-0-387-35634-1_16

Barfod, J. R. (2017). Hvad er militoer ledelse? Hentet fra http://www.fak.dk/publikationer/Pages/Hvadermiltarledelse.aspx

Barrett, F. J., \& Cooperrider, D. L. (1990). Generative Metaphor Intervention: A New Approach for Working with Systems Divided by Conflict and Caught in Defensive Perception. The Journal of Applied Behavioral Science, 26(2), 219-239. https://doi.org/10.1177/0021886390262011

Bévort, F. (2017). Professionalisering af ledelse i spændingsfeltet mellem bureaukrati og profession. Tidsskrift for Arbejdsliv, 19(3), 28-45. https://doi.org/10.7146/tfa.v19i3.109064

Black, M. (1962). Models and metaphors: Studies in language and philosophy. Ithaca, N.Y.: Cornell Univ. Press. 
Boe, O. (2015). Building Resilience: The Role of Character Strengths in the Selection and Education of Military Leaders. International Journal of Emergency Mental Health and Human Resilience, O(0). https://doi.org/10.4172/1522-4821.1000301

Boe, O., \& Bang, H. (2016). The Big 12: The Most Important Character Strengths for Military Officers. ATINER'S Conference Paper Serie, PSY2016.

Borre, M. (2014, april 10). EL: Nu kan skandalerne i forsvaret fortsætte. Politiken. Hentet fra https://politiken.dk/indland/politik/art5510715/EL-Nu-kan-skandalerne-i-forsvaretforts\%C3\%A6tte

Bousquet, A. (2009). The scientific way of warfare: Order and chaos on the battlefields of modernity. New York: Columbia University Press.

Boxenbaum, E., \& Rouleau, L. (2011). New Knowledge Products As Bricolage: Metaphors and Scripts in Organizational Theory. The Academy of Management Review, 36(2), 272-296.

https://doi.org/10.5465/AMR.2011.59330898

Burke, K. (1945). A Grammar of Motives. Hentet fra

https://books.google.dk/books?id=kl0NAQAAIAAJ

Calhoun, M. T. (2011). Clausewitz and Jomini: Contrasting Intellectual Frameworks in Military Theory. Army History, (80), 22-37. Hentet fra JSTOR.

Carli, L. L., \& Eagly, A. H. (2016). Women face a labyrinth: An examination of metaphors for women leaders. Gender in Management: An International Journal, 31(8), 514-527.

https://doi.org/10.1108/GM-02-2015-0007

Carvalho, T. (2012). Managerialism and professional strategies: A case from nurses in Portugal. Journal of Health Organization and Management, 26(4), 524-541.

https://doi.org/10.1108/14777261211251562

Clemmesen, M. H. (2015). Fortsættelse. Videregående officersuddannelse: Del 3Afprofessionaliseringen. Krigsvidenskab.dk online. Hentet fra http://www.krigsvidenskab.dk/videregaaende-officersuddannelse-del-3-afprofessionaliseringen

Cornelissen, J. P. (2005). Beyond Compare: Metaphor in Organization Theory. The Academy of Management Review, 30(4), 751-764. https://doi.org/10.2307/20159166 
Cornelissen, J. P., \& Kafouros, M. (2008). The Emergent Organization: Primary and Complex Metaphors in Theorizing about Organizations. Organization Studies, 29(7), 957-978. https://doi.org/10.1177/0170840608090533

Cornelissen, J. P., Kafouros, M., \& Lock, A. R. (2005). Metaphorical images of organization: How organizational researchers develop and select organizational metaphors. Human Relations, 58(12), 1545-1578. https://doi.org/10.1177/0018726705061317

Cornelissen, J. P., Oswick, C., Christensen, L. T., \& Phillips, N. (2008). Metaphor in Organizational Research: Context, Modalities and Implications for Research - Introduction. Organization Studies, 29(1), 7-22. https://doi.org/10.1177/0170840607086634

Forrester, G. (2000). Professional autonomy versus managerial control: The experience of teachers in an english primary school. International Studies in Sociology of Education, 10(2), 133-151. https://doi.org/10.1080/09620210000200056

Gregor, W. J. (2010). Military Planning Systems and Stability Operations. PRISM, 1(3), 99-114. Hentet fra JSTOR.

Greve, L. (2016). Using metaphor as a management tool. I The Routledge Handbook of Metaphor and Language (s. 400-412). https://doi.org/10.4324/9781315672953.ch27

Hagedorn-Rasmussen, P., Krause-Jensen, J., \& Mogensen, M. (2017). Ledelse som professionMellem idé og praksis. Tidsskrift for Arbejdsliv, 19(3), 5-10.

https://doi.org/10.7146/tfa.v19i3.109062

Hald, C., \& Rønn, K. V. (2013). Om at opdage: Metodiske refleksioner over politiets undersøgelsespraksis. Frederiksberg C: Samfundslitteratur.

Heltberg, T., \& Jellesmark, T. (2017). What Difference Does a Difference Make? Considerations About Lessons Learned from Difficult Operational Situations. I M. Holenweger, M. K. Jager, \& F. Kernic (Red.), Leadership in Extreme Situations (s. 295-321). https://doi.org/10.1007/978-3-31955059-6

Heracleous, L., \& Jacobs, C. D. (2008). Understanding Organizations through Embodied Metaphors. Organization Studies, 29(1), 45-78. https://doi.org/10.1177/0170840607086637 
Holsting, V. S. (2017). Militcert chefvirke: Kritik og retfoerdiggørelse mellem politik og profession. Frederiksberg: Copenhagen Business School [Phd], 2017.

Hovedorganisationen af Officerer i Danmark. (2017). Forsvarsforlig i et officersperspektiv (s. 44).

Jacobs, C. D., \& Heracleous, L. Th. (2006). Constructing Shared Understanding: The Role of Embodied Metaphors in Organization Development. The Journal of Applied Behavioral Science, 42(2), 207-226. https://doi.org/10.1177/0021886305284895

Jermier, J. M., \& Forbes, L. C. (2011). Metaphor as the Foundation of Organizational Studies: Images of Organization and Beyond. Organization \& Environment, 24(4), 444-458. https://doi.org/10.1177/1086026611436328

Kemp, L. J. (2016). ‘Trapped’ by metaphors for organizations: Thinking and seeing women’s equality and inequality. Human Relations, 69(4), 975-1000.

https://doi.org/10.1177/0018726715621612

Kendall, J. E., \& Kendall, K. E. (1993). Metaphors and Methodologies: Living beyond the Systems Machine. MIS Quarterly, 17(2), 149-171. https://doi.org/10.2307/249799

Kirkpatrick, I., \& Ackroyd, S. (2003). Archetype Theory and the Changing Professional Organization: A Critique and Alternative. Organization, 10(4), 731-750.

https://doi.org/10.1177/13505084030104005

Knudsen, H., Olesen, K. G., Bojesen, A., \& Gleerup, J. (2014). Ledelse og velfærdsprofessioner. Tidsskrift for Arbejdsliv, 16(1), 5-10.

Lakoff, G., \& Johnson, M. (1980). Metaphors we live by. Chicago: University of Chicago Press.

Latusek, D., \& Vlaar, P. W. (2015). Exploring managerial talk through metaphor: An opportunity to bridge rigour and relevance? Management Learning, 46(2), 211-232.

https://doi.org/10.1177/1350507614529512

Linn, G. B., Sherman, R., \& Gill, P. B. (2007). Making Meaning of Educational Leadership: The Principalship in Metaphor. NASSP Bulletin, 91(2), 161-171.

https://doi.org/10.1177/0192636507302095

Lund, S. K. (2017). Udviklingen og anvendelsen af dansk forsvars landmilitære doktrin. Krigsvidenskab.dk, 10. 
Lundberg, A., Artéus, G., Wijnbladh, C., \& Försvarshögskolan. (1997). Vägar till svensk officersetik: Grundtext till militär etikutbildning. Stockholm: Försvarshögskolan.

Marshak, R. J. (1993). Managing the metaphors of change. Organizational Dynamics, 22(1), 44-56. https://doi.org/10.1016/0090-2616(93)90081-B

Mintzberg, H. (2005). Managers Not MBAs: A Hard Look at the Soft Practice of Managing and Management Development. San Francisco, Calif: Berrett-Koehler Publishers.

https://doi.org/10.5465/ame.2004.15268779

Mintzberg, H. (2009). Managing. Hentet fra http://www.books24x7.com/marc.asp?bookid=31829

Morgan, G. (1986). Images of organization (1st ed.). Thousand Oaks, California: SAGE Publ.

Morgan, G. (2006). Images of organization (3rd ed.). Thousand Oaks, California: SAGE Publications.

Morgan, G. (2011). Reflections on Images of Organization and Its Implications for Organization and Environment. Organization \& Environment, 24(4), 459-478.

https://doi.org/10.1177/1086026611434274

Morgan, G. (2017). Foreword. I A. Örtenblad, K. Trehan, \& L. L. Putnam (Red.), Exploring Morgan's metaphors: Theory, research, and practice in organizational studies (s. xiii-xxix). Los Angeles: SAGE. https://doi.org/10.4135/9781506318752

Mottelson, M. (2018). Ind i poedagogikken. Kbh.: Akademisk Forlag.

Møller, H. H. (2013). Kunst på det operative niveau. Militaert Tidsskrift, 141. årgang(nr. 4), 25-41.

Nørgaard, K., \& Holsting, V. S. (2014). Militor ledelse i et professionsperspektiv. Hentet fra http://www.fak.dk/publikationer/Pages/Militaerledelseietprofessionsperspektiv.aspx

Nørgaard, K., Holsting, V. S., \& Schultz-Larsen, S. E. (2015). Det militcerfaglige råd og embedsvirke. Kbh.: Forsvarsakademiet.

Nørgaard, K., Holsting, V. S., \& Thorbjørnsen, S. R. (2008). Militcer etik og ledelse i praksis. København: Forsvarsakademiet. 
Perreault, G. (1996). Metaphors for Leadership: Military Battle and Friendship. Journal of Leadership Studies, 3(1), 49-63. https://doi.org/10.1177/107179199600300106

Putnam, L. L., \& Boys, S. (2006). Revisiting Metaphors of Organizational Communication. I The SAGE Handbook of Organization Studies (s. 541-576).

https://doi.org/10.4135/9781848608030.n19

Rasmussen, P. E. (2018, oktober 18). Anklager om nepotisme og magtmisbrug mod generalmajor. Hentet 28. november 2018, fra OLFI website: https://olfi.dk/2018/10/18/anklager-om-nepotismeog-magtmisbrug-mod-haerchef-og-generalmajor/ https://doi.org/10.23865/noasp.47

Robl, L. (2012, februar 15). Forsvarets ledelseskultur har fatale konsekvenser. Politiken. Hentet fra https://politiken.dk/debat/art5418388/Forsvarets-ledelseskultur-har-fatale-konsekvenser Ruth, D. (2014). Leader as priest: Plucking the fruit of a flawed metaphor. Leadership, 10(2), 174190. https://doi.org/10.1177/1742715012467488

Schechter, C., Shaked, H., Ganon-Shilon, S., \& Goldratt, M. (2016). Leadership Metaphors: School Principals' Sense-Making of a National Reform. Leadership and Policy in Schools, 1-26. https://doi.org/10.1080/15700763.2016.1232836

Schoeneborn, D., Vásquez, C., \& Cornelissen, J. (2016). Imagining organization through metaphor and metonymy: Unpacking the process-entity paradox. Human Relations, 69(4), 915-944. https://doi.org/10.1177/0018726715612899

Schön, D. A. (1979). Generative Metaphor: A Perspective on Problem-Setting in Social Policy. I A. Ortony (Red.), Metaphor and Thought (s. 254-283). Cambridge; New York: Cambridge University Press. https://doi.org/10.1017/cbo9781139173865.011

Schön, D. A. (1993). Generative Metaphor: A Perspective on Problem-Setting in Social Policy. I A. Ortony (Red.), Metaphor and Thought (2. udg., s. 137-163).

https://doi.org/10.1017/CBO9781139173865.011

Shamir, E. (2011). Transforming command: The pursuit of mission command in the U.S., British, and Israeli armies. Stanford, Calif: Stanford Security Studies.

https://doi.org/10.1080/01402390.2016.1144457 
Smith, K. K., \& Simmons, V. M. (1983). A Rumpelstiltskin Organization: Metaphors on Metaphors in Field Research. Administrative Science Quarterly, 28(3), 377-392.

https://doi.org/10.2307/2392248

Spicer, A., \& Alvesson, M. (2011). Metaphors for leadership. I Mats Alvesson \& André Spicer (Red.), Metaphors we lead by: Understanding leadership in the real world (s. 31-50). Routledge.

https://doi.org/10.3917/mana.144.0264

Svendsen, J., \& Bendtsen, J. V. (2016, juni 3). Soldater: Forsvaret har behov for ny ledelse. Politiken. Hentet fra https://politiken.dk/indland/art5624523/Soldater-Forsvaret-har-behov-for-ny-ledelse

Thyssen, O. (2000). Iagttagelse og blindhed: Om organisation, fornuft og utopi. Kbh.: Handelshøjskolens Forlag.

Tohidian, I., \& Rahimian, H. (2019). Bringing Morgan's metaphors in organization contexts: An essay review. Cogent Business \& Management, 6(1).

https://doi.org/10.1080/23311975.2019.1587808

Tong, S., \& Bowling, B. (2006). Art, Craft and Science of Detective Work. The Police Journal: Theory, Practice and Principles, 79(4), 323-329. https://doi.org/10.1350/pojo.2006.79.4.323

Tsoukas, H. (1991). The Missing Link: A Transformational View of Metaphors in Organizational Science. The Academy of Management Review, 16(3), 566.

https://doi.org/10.5465/amr.1991.4279478

U.S. Department of the Army. (2014). Army Doctrine Reference Publication (ADRP) 6-0: Mission Command. Washington, DC: Headquarters, Department of the Army.

https://doi.org/10.21236/ada401915

Vego, M. (2012). Science vs. The Art of War. Joint Force Quarterly, 66.

Virtanen, T. (2017). Exploring Metaphors of Leadership. I A. Örtenblad, K. Trehan, \& L. L. Putnam, Exploring Morgan's Metaphors: Theory, Research, and Practice in Organizational Studies (s. 138162). https://doi.org/10.4135/9781506318752.n7

Williams, D. (2017). Forensic Vulnerability Analysis: Putting the "Art" into the Art of War. Joint Force Quarterly, 85(2nd Quarter), 36-41. 
Winter, M., \& Szczepanek, T. (2009). Images of projects. Farnham: Gower.

Örtenblad, A., Trehan, K., \& Putnam, L. L. (Red.). (2017). Exploring Morgan's metaphors: Theory, research, and practice in organizational studies. Los Angeles: SAGE.

https://doi.org/10.4135/9781506318752

\footnotetext{
${ }^{i}$ De samme tre metaforer anvendes af Tong og Bowling (2006) samt Hald og Rønn (2013) i relation til politiets efterforskningsarbejde. Disse to studier omtaler dog ikke kunst, håndværk og videnskab som metaforer, men i stedet som tre forskellige typer af logikker, der kan guide efterforskningsarbejdet (Hald \& Rønn, 2013; Tong \& Bowling, 2006, s. 323). Ligeledes har eksempelvis Mottelsen (2018) anvendt metaforerne i forhold til pædagogiske ideer. Men hvor Mottelsons perspektiv primært retter sig mod metaforernes idemæssig baggrund, arbejder vi her med metaforer som en integreret del af praksis og har ikke sporet dem tilbage til deres idemæssige ophav.

ii Disse publikationer om militær ledelse relaterer til så forskelligartede områder som f.eks. karaktertræk og ledelsesstile blandt officerer, officersprofessionen, militær etik og det militære chefvirke.

iii Forsvarsakademiet ansøgte i første halvår af 2011 om akkreditering af det daværende Stabskursus som en Master i Militære Studier (MMS). Akkrediteringsrådet godkendte i 2014 denne ansøgning samt en ansøgning om tilrettelægning af officersuddannelsen som en diplomuddannelse. Masteruddannelsen havde sit første optag i sommeren 2015.

iv Det er i øvrigt også i forlængelse af Burke, som netop fremhæver, at metaforer må forstås som perspektiver: "[T]o consider A from the point of view of B is, of course, to use B as a perspective upon A" $(1945$, s. 504)

$v$ "How we conceptualize and talk about ourselves and others influences what we become. Theories function to produce responses which produce ourselves, our social interaction, our institutions, and our collective future." (Alvesson \& Deetz, 2000, s. 45)

vi "When we see A as B, we carry over to A the evaluation implicit in B." (Schön, 1993, s. 147)

vii De metaforer, som er blevet så selvfølgelige, at vi glemmer, at der overhovedet er tale om en metaforer, når vi anvender dem, betegner Cornelissen og Kafouros som "døde metaforer" (2008, s. 859).

viii Yderligere forskning kan undersøge dominerende metaforer i den militære praksis. Se diskussionsafsnittet nedenfor.

${ }^{i x h t t p: / / m e d a r b e j d e r . f o r s v a r e t . d k / s t r a t e g i-p o l i t i k / t a l e n t-~}$

management/Documents/Koncept\%20for\%20Talent\%20Management\%20i\%20FMN\%20Koncern.pdf (hentet 10 . oktober 2018).

“ I forlængelse heraf kan det bemærkes, at begrebet "professionalisering" i sig selv kan ses som en metafor. I dette perspektiv ville det være interessant eksempelvis at undersøge, hvilke værdier, som denne metafor fremhæver, og hvilke den skubber i baggrunden, og hvordan dette har forandret sig over tid.
} 